\title{
Xavier Seuba: The Global Regime for the Enforcement of Intellectual Property Rights
}

Cambridge University Press, 2017. 494 pp. ISBN: 9781108415163. $£ 110.00$

\author{
Dieter Stauder $\cdot$ Stefan Luginbühl
}

Published online: 4 June 2018

(C) Max Planck Institute for Innovation and Competition, Munich 2018

With The Global Regime for the Enforcement of Intellectual Property Rights Xavier Seuba has filled a legal scientific gap and shed light on the definition and qualification of IPR enforcement from the point of view of international public law in its greatest variety. He provides an overview of different global IP-related international treaties, and how these deal with the subject of the enforcement of IPRs. Furthermore, he analyses the enforcement of IPRs from the perspective of human rights and their protection, in particular in relation to the protection of property and procedural rights, but also in relation to the proportionality of IPR enforcement. This is followed by an analysis of economic studies in the area of IP, which reveals a lack of research on the economic impact of the enforcement of IPRs, in particular as regards the investment necessary to set up and run an enforcement system for IPRs. As Seuba puts it: "Economic estimates of the impact of IP do not generally reflect the net impact of IP." Finally, the author deals with more traditional aspects of IPR enforcement, such as civil and criminal enforcement, and boarder measures with thought-provoking reflections on the different legal areas of enforcement from a global legal point of view.

A great value of the book is the documentation of material, especially treaties and laws of different countries from all over the world. This publication is directed to public institutions and government offices and is an excellent resource for many questions related to public and international public law which are not raised in most books on intellectual property.

\footnotetext{
D. Stauder

Dr. iur.; Ancien Professeur Université Robert Schuman, Bardehle Pagenberg, Munich, Germany e-mail: stauder@bardehle.de
}

\section{S. Luginbühl $(\bowtie)$}

Ph.D.; Attorney-at-Law, European Patent Office, Munich, Germany

e-mail: sluginbuehl@epo.org 